\title{
Peary Caribou and Muskoxen on Banks Island
}

\author{
PETER G. KEVAN ${ }^{1}$
}

\begin{abstract}
Peary caribou and muskoxen were surveyed on Banks Island north of $73^{\circ} \mathrm{N}$. in June 1970 to identify critical spring ranges of these animals. The data gathered also lend themselves to population estimations. Critical spring ranges of both animals north of $73^{\circ} \mathrm{N}$. are more or less mutually exclusive. Muskoxen were restricted to the eastern side of the island; caribou were widely dispersed and associated with simpler plant communities. Group and herd structures for both animals are given and indicate high productivity. Conservative population estimates indicate far more animals than previously supposed: $5,300-8,000$ caribou and $1,200-1,300$ muskoxen.
\end{abstract}

RÉSUMÉ. Le caribou de Peary et le bouf musqué dans l'île de Banks. En juin 1970, on a inventorié les caribous de Peary et les boufs musqués dans l'île de Banks au nord du $73^{\circ} \mathrm{N}$, afin d'identifier les aires printanières critiques de ces animaux. Les données recueillies se prêtent également à des estimés de population. Au nord du $73^{\circ}$ N., les aires printanières critiques de ces deux espèces s'excluent plus ou moins l'une l'autre. Les bœufs musqués ne se trouvent que du côté est de l'île; les caribous sont largement dispersés et associés aux communautés de plantes les plus simples. On donne les structures de groupe et de troupeau pour les deux espèces; elles indiquent une haute productivité. Des estimés de population conservateurs indiquent un plus grand nombre d'animaux qu'on ne le supposait auparavant: de 5,300 à 8,000 caribous et de 1,200 à 1,300 bcufs musqués.

PE3ЮME. Пири карибу/Rangifer tarandus pearyi /u мускусный бык/Ovibos moschatus /на о. Банксе. С целью определения границ весенних пастбищ Пири карибу и мускусного быка ва этими животными в июне 1970 года велось наблюдение на о.Банксе выше $73^{\circ}$ с.ш. Собранные данные были использованы также для оценки численности обеих популяций. Выше $73^{\circ}$ с.п. границы весенних пастбищ Пири карибу и мускусного быка практически не перекрываются. Мускусный бык сосредоточен в восточной части острова, в то время как Пири карибу рассеян по широкой территории и довольствуется менее прихотливой растительностью. Приводимые в работе данные по структуре трупп и стад указывают на высокую продуктивность животных обоих видов. Даже по заниженным оценкам численность особей в популяциях значительно iревынтет ранее предполагавшуюся и составляет 5,3-8,0 тыс. карибу и 1,2-1,3 тыс. мускусных быков.

\section{INTRODUCTION}

This study was part of a project designed to identify and map critical spring ranges of Peary caribou (Rangifer tarandus pearyi) and muskoxen (Ovibos moschatus) on Banks Island, Northwest Territories. Aerial surveys were carried out to locate caribou and muskoxen, as little was known of their distribution and numbers. The estimation of populations of the species was not an objective of this study, and markers on the aircraft were not used to measure the areas surveyed. However, it became apparent upon completion of the surveys that the populations of both

\footnotetext{
1Research Unit on Vector Pathology, Memorial University of Newfoundland, St. John's,
} Newfoundland. 
caribou (Stefansson 1921; Manning and Macpherson 1958; Macpherson 1960) and muskoxen (Tener 1958; Macpherson 1960) were much greater than previously estimated. Therefore, data are presented for estimating the populations of caribou and muskoxen on Banks Island.

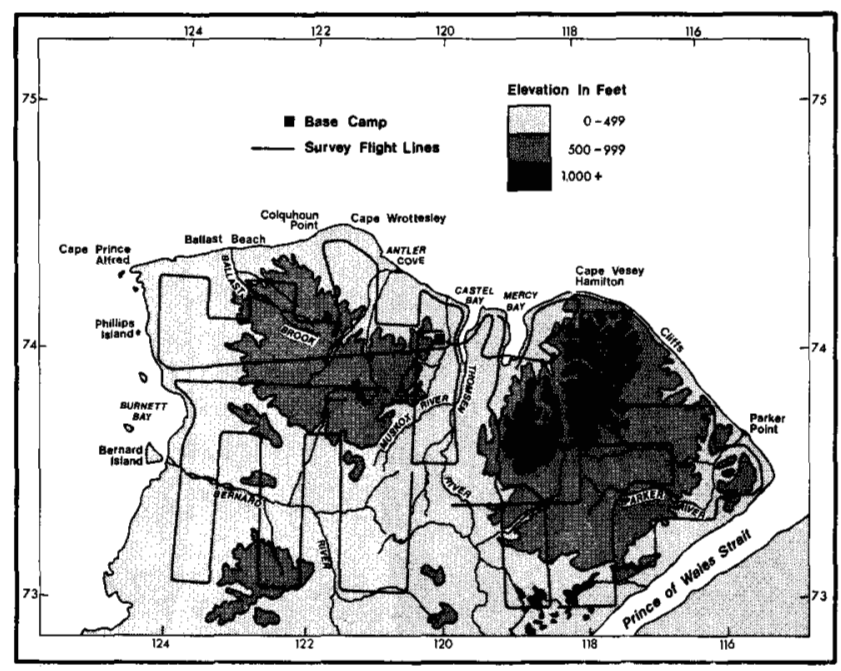

FIG. 1. Northern Banks Island showing survey flight lines, major watersheds, and topography.

\section{METHODS}

Spring ranges of caribou and muskoxen are on the northern part of Banks Island (Macpherson 1960; Barry, personal communication; Williams, personal communication). A base camp was established near the north coast at Castel Bay $\left(74^{\circ} 09^{\prime}\right.$ N., $119^{\circ} 59^{\prime}$ W.) (Fig. 1). The survey was conducted between 23 and 28 June 1970 . This is probably about two weeks after calving by caribou is mostly over, and many weeks after calving by muskoxen (Tener 1965).

A Cessna 185 aircraft was flown at 500 feet $(150 \mathrm{~m}$.) above the ground. It was intended to follow a course on every second $10 \mathrm{~km}$. mercator grid line to evenly cover Banks Island north of $73^{\circ} \mathrm{N}$., and so to try to locate all areas with relatively high numbers of animals. The flight lines had to be modified due to vagaries in weather and limited time. As animals and herds were counted, they were located on 1:250,000 topographical maps. Terrain types were noted and snow cover was estimated in tenths.

\section{Recognition of terrain types}

From the information gathered as animals were located and counted, it was possible to distinguish four general categories of terrain, as follows:

1. Barren areas, which fall into two categories:

(a) higher land comprising an arctic desert of stony fellfield. In some areas, stripes of vegetation with Kobresia myosuroides, Dryas integrifolia, Potentilla rubricaulis, Oxytropis arctica, some Carex spp., Cruciferae, Saxifraga oppositifolia, etc., occur (Porsild 1955). 
(b) gravel and sand bars of rivers, which, being periodically flooded and unstable, are without vegetation.

2. Wet areas of flat-patterned ground with well-developed polygons and standing water. Vegetation in such areas is characterized by Eriophorum scheuchzeri, Carex aquatalis, and other sedges in continuous mats.

3. Well-drained areas on slopes, hills, or knolls without well-developed hummocks. In some areas Dryas integrifolia and Kobresia myosuroides predominate.

4. - Well-drained areas on slopes steeper than those of (3). These have welldeveloped hummocks of Dryas integrifolia and Cassiope tetragona which grade into type (3) at higher, and type (2) at lower, levels via drier tussocky sedge meadows.

\section{Population estimation}

Because of the pattern of dispersion of animals and the heterogeneity of habitat, no valid determination of population density could be made from the total area surveyed, number of animals, and total area of Banks Island north of $73^{\circ} \mathrm{N}$. Some stratification of population density was attempted, but even within each stratum the heterogeneity of habitat and random dispersion of animals rendered the data invalid. Population densities were worked out on the basis of the numbers of animals seen per kilometre surveyed. It may be deduced from the plotted flight course, and the position of landmarks and animals located on the map, that strips, one kilometre wide, on each side of the aircraft were almost completely covered

TABLE 1. Estimates of distribution and population of caribou on Banks Island, June 1970.

\begin{tabular}{|c|c|c|c|c|c|c|}
\hline $\begin{array}{l}\text { Name of area } \\
\text { (see Fig. 1) }\end{array}$ & $\begin{array}{l}\text { Area } \\
\mathrm{km} .^{2}\end{array}$ & $\begin{array}{l}\% \text { of total } \\
\text { surveyed } \\
\text { area }\end{array}$ & $\begin{array}{l}\text { Number } \\
\text { of animals } \\
\text { seen }\end{array}$ & $\begin{array}{c}\text { Number } \\
\text { per } \\
\text { km. }\end{array}$ & $\begin{array}{c}\% \text { of } \\
\text { population }\end{array}$ & $\begin{array}{c}\text { Estimated } \\
\text { population } \\
(2 \mathrm{~km} \text {. strip })\end{array}$ \\
\hline \multicolumn{7}{|l|}{$\begin{array}{l}\text { Caribou (1 yr. or more } \\
\text { old) with calves }\end{array}$} \\
\hline Burnett Bay $\mathbf{M}^{*}$ & 760 & 1.9 & $25+9$ & $.57+.25$ & $6.2+6.2$ & $217+95$ \\
\hline Burnett Bay $\mathbf{H}^{*}$ & 1114 & 4.5 & $91+13$ & $.90+.13$ & $14.4+8.0$ & $501+123$ \\
\hline Colquhoun Point & 314 & 1.1 & $24+13$ & $.92+.50$ & $4.1+5.2$ & $145+79$ \\
\hline Antler Cove & 527 & 1.6 & $16+13$ & $.48+.35$ & $3.3+6.0$ & $118+92$ \\
\hline Mercy Bay & 2481 & 10.2 & $146+81$ & $.64+.36$ & $22.9+29.3$ & $794+447$ \\
\hline N.E. Plateau & 273 & 0.9 & $22+10$ & $1.05+.48$ & $4.1+4.4$ & $144+67$ \\
\hline Remaining habitable & 31067 & 72.9 & $157+65$ & $.10+.04$ & $44.8+40.8$ & $1554+662$ \\
\hline N.E. Plateau snow & 2268 & 6.3 & $0+0$ & $0+0$ & $0+0$ & $0+0$ \\
\hline TOTALS & 38804 & 99.4 & $481+204$ & - & $99.9+99.9$ & $3473+1525$ \\
\hline \multicolumn{7}{|l|}{$\begin{array}{l}\text { Caribou (1 yr. or more } \\
\text { old }) \text { without calves }\end{array}$} \\
\hline Castel Bay & 679 & 5.3 & 22 & .10 & 1.1 & 34 \\
\hline Colquhoun Point & 182 & 1.0 & 21 & .90 & 2.8 & 82 \\
\hline Mercy Bay & 250 & 1.2 & 15 & .60 & 2.5 & 75 \\
\hline Burnett Bay & 1144 & 5.1 & 76 & .68 & 13.1 & 389 \\
\hline Remaining habitable & 34281 & 81.0 & 259 & .14 & 80.5 & 2400 \\
\hline N.E. Plateau snow & 2286 & 6.3 & 0 & 0 & 0 & 0 \\
\hline TOTALS & 38804 & 99.9 & 393 & - & 100.0 & 2980 \\
\hline GRAND TOTAL & & & & & & 7978 \\
\hline
\end{tabular}

* $M$ is medium density, $H$. is high density. 
by the observers. Stephen (1970) estimated that all animals in strips $1.6 \mathrm{~km}$. wide extending on both sides of the aircraft were counted. Because of the bad weather and the short time available, survey periods on clear days were considerably longer than Tener's (1963) suggested maximum of three hours (the longest from about 1500 hours M.S.T. on 27 June until about 0900 hours M.S.T. on 28 June, with short stops).

\section{RESULTS}

It is shown in Fig. 1 that coverage of the island was fairly uniform, Burnett Bay, Mercy Bay, and possibly Colquhoun Point receiving however slightly more attention than the remaining areas (Table 1).

The sizes, locations, and composition of groups of caribou one year or more old, respectively with and without calves, and muskoxen, are shown in Fig. 2. Numbers of animals both on and off survey lines were recorded by showing the areas of greatest concentration of them in each category. The extent of snow covering more than 90 percent of the ground is also indicated.

Neither caribou nor muskoxen are evenly distributed throughout the survey area. Muskoxen appear to be limited to the eastern part of the island and a line, the "muskoxen line", has been drawn on Fig. 2 to suggest the greatest extent of the area in which they might be found - at least in late June. Caribou are widely spread, but are apparently more common in the west. Both species are common in the area of Mercy Bay and Castel Bay, and the northern part of the Thomsen River, but even here segregation is apparent.

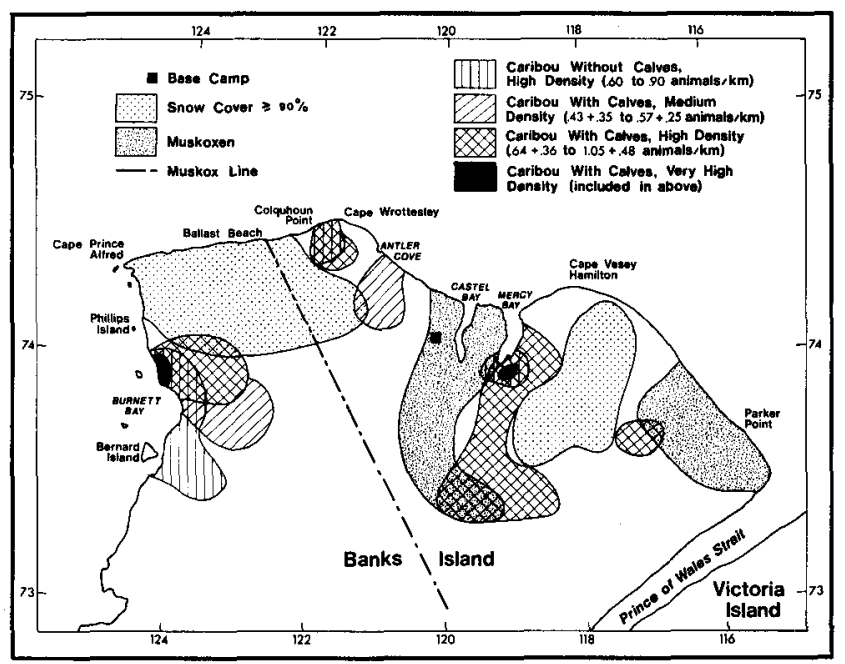

FIG. 2. Northern Banks Island showing areas of above-average densities of caribou and muskoxen, and areas of extensive snow cover.

\section{Caribou: population dispersion and habitat selection'}

From Table 1 and Fig. 2 it is clear that the areas chosen as high-density ones for caribou with calves have considerably more animals - from $0.64+0.36$ to $1.05+0.48$ animals per kilometre surveyed (the plus signs link caribou one year or more old with calves of the year $)$ - than do medium-density areas $(0.43+$ 
0.35 to $0.57+0.25$ animals per kilometre). These higher-density areas have about 5 to 10 times the density of the average.

Of the caribou groups with calves, $55 \%$ of those one year or more old, and $59 \%$ of the calves of the year, were found in the high-population-density areas, which represented only $14.2 \%$ of the total area (Table 1). Of the caribou one year or more old without calves, $18.4 \%$ were found in the high-population-density areas, which represented $3.9 \%$ of the total area. The breeding population was far more restrictive in its choice of habitat than the non-breeding population. Tradition and social cohesion need possibly to be taken into account for certain geographical regions - or segregation, or intraspecific strife, or combinations of such factors. Some caribou were wide-ranging and were to be found on all types of terrain, unless the ground was snow-covered (Table 2).

TABLE 2. Caribou and muskoxen observed on different habitat types, Banks Island, June 1970.

\begin{tabular}{|c|c|c|c|c|c|}
\hline Terrain types & $\begin{array}{c}\text { Caribou } \\
(\geq 1 \text { yr.) } \\
\text { with calves }\end{array}$ & $\begin{array}{c}\text { Caribou } \\
(\geq 1 \text { yr.) } \\
\text { without calves }\end{array}$ & $\begin{array}{l}\text { Muskoxen } \\
(\geq 1 \text { yr.) } \\
\text { with calves }\end{array}$ & $\begin{array}{c}\text { Muskoxen } \\
\text { ( } \geq 1 \text { yr.) } \\
\text { without calves }\end{array}$ & $\begin{array}{l}\text { Single or paired } \\
\text { muskoxen } \\
(\geq 1 \mathrm{yr} .)\end{array}$ \\
\hline $\begin{array}{l}\text { Stony barrens } \\
\text { Wet areas } \\
\text { Well-drained } \\
\text { with undeveloped }\end{array}$ & $\begin{array}{c}29+13(8) \\
72+27(34) \\
213+95(51)\end{array}$ & $\begin{array}{r}23(13) \\
99(44) \\
158(63)\end{array}$ & $\begin{array}{c}0+0(0) \\
125+32(8) \\
0+0(0)\end{array}$ & $\begin{array}{r}0(0) \\
9(2) \\
15(4)\end{array}$ & $\begin{array}{c}0(0) \\
9(7) \\
18(14)\end{array}$ \\
\hline $\begin{array}{l}\text { Slopes with } \\
\text { developed hummocks }\end{array}$ & $153+73(36)$ & $70(30)$ & $149+35(14)$ & $4(1)$ & $11(7)$ \\
\hline $\begin{array}{l}\text { On snow } \\
\text { Unknown }\end{array}$ & $\begin{array}{c}0+0(0) \\
38+22(13)\end{array}$ & $\begin{array}{c}0(0) \\
43(22)\end{array}$ & $\begin{array}{rr}0+0 & (0) \\
47+9 & (4)\end{array}$ & $\begin{array}{r}0(0) \\
10(2)\end{array}$ & $\begin{array}{l}0(0) \\
1(1)\end{array}$ \\
\hline
\end{tabular}

Numbers in parentheses are the numbers of groups seen.

\section{Caribou population estimates}

Population estimates for Banks Island caribou are few and incomplete. Stefansson (1921) estimated the population to be 2,000-3,000 animals. Manning and Macpherson (1958) estimated 4,000 animals in the 1952-53 period. Macpherson (1960) estimated there were 2,351 animals and suggested (1959) that overcrowding had reduced the numbers since 1953. McEwen (1952) suggested that this reduction of the population was due to environmental factors.

The estimate of the caribou population presented here (Table 1) exceeds previous estimates by 2.5 to 1.5 times. If animals seen off survey lines are included, there were more than $513+245$ in groups of animals with calves, and a further 389 in groups without calves, for a total 1,147 seen on and off the survey lines; or 1,078 seen on the survey lines alone (Table 1). It is most unlikely that one half, or even a quarter, of the population were seen. Thus, an estimate that the population of caribou on Banks Island north of $73^{\circ} \mathrm{N}$. is between 5,300 and 8,000 must be regarded as a conservative one.

\section{Caribou group structures}

Peary caribou on Banks Island probably migrate northward as the snow melts. At the time of the survey, there did not appear to be a preponderance of females 
in the north, and small bands of animals near the camp were composed entirely of males. However, no precise information on the sex ratio of the animals observed during the aerial survey was collected. If one makes the assumption, albeit poor, that males and females segregate into small bands - females being associated with calves - the sex ratio, calculated from Table 1, is 82 males: 100 females. Based on the total population, the percentage of calves was about 19.0, a figure which agrees well with other data for Peary caribou (Tener 1963).

The size of groups of caribou with calves varied greatly, ranging from 1 female +1 calf to 28 caribou (one year or more old) +4 calves, and from 1 to 9 caribou without calves (Table 3). Savile (1961) records only small groups on Ellef Ringnes Island with its even more rigorous conditions than those of Banks Island.

TABLE 3. Frequency of occurrence of sizes and structure of groups of Peary caribou and muskoxen on Banks Island, June 1970.

\begin{tabular}{|c|c|c|c|c|c|c|c|c|}
\hline $\begin{array}{l}\text { Age } \\
\text { composition } \\
\geq 1 \text { year } \\
\text { +calves }\end{array}$ & $\begin{array}{l}\text { Caribou: } \\
\text { times } \\
\text { observed }\end{array}$ & $\begin{array}{l}\text { Muskoxen: } \\
\text { times } \\
\text { observed }\end{array}$ & $\begin{array}{l}\text { Age } \\
\text { composition } \\
\geq 1 \text { year } \\
+ \text { calves }\end{array}$ & $\begin{array}{l}\text { Caribou: } \\
\text { times } \\
\text { observed }\end{array}$ & $\begin{array}{l}\text { Muskoxen: } \\
\text { times } \\
\text { observed }\end{array}$ & $\begin{array}{l}\text { Age } \\
\text { composition } \\
\geq 1 \text { year } \\
+ \text { calves }\end{array}$ & $\begin{array}{l}\text { Caribou: } \\
\text { times } \\
\text { observed }\end{array}$ & $\begin{array}{l}\text { Muskoxen: } \\
\text { times } \\
\text { observed }\end{array}$ \\
\hline $\begin{array}{l}1+1 \\
1+2\end{array}$ & $\begin{array}{r}18 \\
1\end{array}$ & & $\begin{array}{l}7+3 \\
7+4 \\
7+5\end{array}$ & $\begin{array}{l}1 \\
3 \\
1\end{array}$ & $\begin{array}{l}1 \\
1\end{array}$ & $\begin{array}{l}13+2 \\
13+4\end{array}$ & & $\begin{array}{l}3 \\
1\end{array}$ \\
\hline $\begin{array}{l}2+1 \\
2+2\end{array}$ & $\begin{array}{l}17 \\
12\end{array}$ & 1 & $8+1$ & & 1 & $14+4$ & 1 & \\
\hline $2+3$ & 3 & & $\begin{array}{l}8+2 \\
8+3\end{array}$ & 2 & 1 & $\begin{array}{l}16+4 \\
16+5\end{array}$ & & $\begin{array}{l}1 \\
1\end{array}$ \\
\hline $\begin{array}{l}3+1 \\
3+2 \\
3+3\end{array}$ & $\begin{array}{r}13 \\
7 \\
1\end{array}$ & & $\begin{array}{l}8+4 \\
9+1\end{array}$ & 1 & 1 & $24+4$ & & 1 \\
\hline $\begin{array}{l}4+1 \\
4+2 \\
4+3\end{array}$ & $\begin{array}{r}10 \\
7 \\
5\end{array}$ & & $\begin{array}{l}9+2 \\
9+3 \\
9+5\end{array}$ & $\begin{array}{l}2 \\
2 \\
1\end{array}$ & 1 & $\begin{array}{l}28+4 \\
30+5\end{array}$ & 1 & 1 \\
\hline $4+4$ & 2 & & $\begin{array}{l}10+1 \\
10+4\end{array}$ & & $\begin{array}{l}1 \\
1\end{array}$ & $54+6$ & & 1 \\
\hline $\begin{array}{l}5+1 \\
5+2 \\
5+3 \\
5+4\end{array}$ & $\begin{array}{l}4 \\
3 \\
4 \\
1\end{array}$ & 3 & $\begin{array}{l}10+6 \\
11+2 \\
11+8\end{array}$ & 1 & $\begin{array}{l}1 \\
1\end{array}$ & $\begin{array}{l}1+0 \\
2+0 \\
3+0 \\
4+0 \\
5+0\end{array}$ & $\begin{array}{r}56 \\
56 \\
23 \\
9 \\
13\end{array}$ & $\begin{array}{r}17 \\
11 \\
2 \\
4 \\
2\end{array}$ \\
\hline $\begin{array}{l}6+1 \\
6+3 \\
6+3 \\
6+4\end{array}$ & $\begin{array}{l}3 \\
1 \\
2 \\
1\end{array}$ & 1 & $\begin{array}{l}12+1 \\
12+3\end{array}$ & 1 & 1 & $\begin{array}{l}6+0 \\
7+0 \\
8+0 \\
9+0\end{array}$ & $\begin{array}{l}7 \\
4 \\
1 \\
1\end{array}$ & 1 \\
\hline
\end{tabular}

\section{Muskoxen: population dispersion and habitat selection}

The data on muskoxen indicate areas of surprisingly high density (see Table 4). Herds (three or more animals including calves of the year) were found only in the Parker Point and Thomsen River areas. Herds without calves of the year were also found in these same areas and at Colquhoun Point. Single or paired animals were widely dispersed on the eastern part of Banks Island (see "muskox line", Fig. 2) but were scarce, having a population density of between 0.01 and 0.06 animals per kilometre. Thomsen River and Parker Point had the highest population densities. Herds of muskoxen, whether with calves of the year or not, showed even greater preference for particular habitats than did lone animals, all but $4.9 \%$ 
TABLE 4. Estimates of distribution and population of muskoxen (1 year or more old) on Banks Island, June 1970.

\begin{tabular}{|c|c|c|c|c|c|c|}
\hline Name of area & $\underset{\left(\mathrm{km}^{2}\right)}{\text { Area }}$ & $\begin{array}{l}\% \text { of total } \\
\text { surveyed } \\
\text { area }\end{array}$ & $\begin{array}{l}\text { Number of } \\
\text { animals } \\
\text { seen }\end{array}$ & $\begin{array}{l}\text { Number } \\
\text { per km. }\end{array}$ & $\begin{array}{c}\% \text { of } \\
\text { population }\end{array}$ & $\begin{array}{c}\text { Estimated } \\
\text { population } \\
(2 \mathrm{~km} \text {. strip) }\end{array}$ \\
\hline
\end{tabular}

\begin{tabular}{|c|c|c|c|c|c|c|}
\hline & & & & & & \\
\hline \multicolumn{7}{|l|}{$\begin{array}{l}\geq 2 \text { animals }+ \text { calves } \\
\text { (without calves, } \\
\text { in parentheses) }\end{array}$} \\
\hline \multirow{2}{*}{$\begin{array}{l}\text { Parker Point } \\
\text { Thomsen River } \\
\text { Colquboun Point } \\
\text { Remaining habitable } \\
\text { (east of "muskoxen line") } \\
\text { N. E. Plateau snow }\end{array}$} & $\begin{array}{r}2035 \\
3139 \\
182 \\
13990\end{array}$ & $\begin{array}{r}9.3 \\
23.2 \\
1.8 \\
54.5\end{array}$ & $\begin{array}{r}36+17(16) \\
139+28(14) \\
0+0(3) \\
0+0(0)\end{array}$ & $\begin{array}{l}.30+.15(.14) \\
.48+.10(.05) \\
0+0(.13) \\
0+0\left(\begin{array}{l}0\end{array}\right)\end{array}$ & $\begin{aligned} 28.8+49.3(61.3) \\
71.2+50.7(33.8) \\
0+0(4.9) \\
0+0(0)\end{aligned}$ & 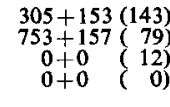 \\
\hline & 2268 & 11.2 & $0+0(0)$ & $0+0(0)$ & $0+0\left(0^{\prime}\right)$ & $0+0 \quad(0)$ \\
\hline TOTAL & 21614 & 100.0 & $175+45(33)$ & $\ldots$ & $100+100(100.1)$ & $1058+310(231)$ \\
\hline
\end{tabular}

\begin{tabular}{|c|c|c|c|c|c|c|}
\hline \multicolumn{7}{|l|}{ Animals singly or in pairs } \\
\hline $\begin{array}{l}\text { Parker Point } \\
\text { Thomsen River } \\
\text { Colquhoun Point } \\
\text { Remaining habitable }\end{array}$ & $\begin{array}{r}2035 \\
3139 \\
182 \\
13990\end{array}$ & $\begin{array}{r}9.3 \\
23.2 \\
1.8 \\
54.5\end{array}$ & $\begin{array}{r}4 \\
18 \\
1 \\
9\end{array}$ & $\begin{array}{l}.03 \\
.06 \\
.04 \\
.01\end{array}$ & $\begin{array}{r}15.4 \\
47.5 \\
1.8 \\
35.4\end{array}$ & $\begin{array}{r}31 \\
94 \\
4 \\
70\end{array}$ \\
\hline N. E. Plateau snow & 2268 & 11.2 & 0 & 0 & 0 & 0 \\
\hline TOTALS & 21614 & 100.0 & 32 & $\ldots$ & 100.0 & 199 \\
\hline GRAND TOTAL & & & & & & 1567 \\
\hline
\end{tabular}

being found in two areas - Thomsen River and Parker Point (Table 2). Single and paired individuals showed less preference for particular habitats, $62.9 \%$ being found in the same two areas.

Muskoxen appear to be more restricted than caribou in their choice of feed. Grasses and sedges, particularly in wet areas, are of prime importance on the Arctic islands (Tener 1965). This fact would account for the recorded dispersion of herds, those on the slopes being associated with the more grassy hummocked areas, or possibly with Salix spp. which they also eat. One lone bull near the camp pawed and ate a clump of Potentilla - though only perhaps as a displacement activity resulting from the proximity of his observers.

\section{Muskoxen population estimates}

Population studies on Banks Island muskoxen have been few and incomplete. Tener (1958) estimated there to be only 100 animals, and this figure was upheld by Macpherson (1960) because, although he estimated a population of 1,114 animals, his survey route was not for game and was most unrepresentative of the island. Maher and Holmes (1963) saw 60 on one flight in 1963.

The estimates in Table 4 of a population between 1,191 and 1,798 muskoxen are again greatly in excess of previous estimates. It is unlikely that herds were seen more than once, although three herds each of $13+2$ and $5+1$ were recorded. A total of 470 animals were counted by actual sightings. The calculated estimate is related to an assumed sighting of about $25 \%$ of all muskoxen north of $73^{\circ} \mathrm{N}$.

\section{Muskoxen: group and herd structures}

Tener (1965) discusses calving and calf production in muskoxen. From the present study calf production was calculated to be $17.8 \%$ of the population of 
herds, or $16.0 \%$ of the total population (Tables 3,4$)$. The second figure is comparable with Tener's (1965) data, although a little higher than most of his values.

Herd size is discussed by Tener (1965) and is variable. From the present study the sizes of 26 herds with calves (Table 3 ) are found to range from $2+1$ (adults and calves) to $54+6$, with an average size of $12.4+3$ calves. These figures agree well with Tener's data, but are slightly higher. Herds without calves averaged (present study) 4.5 animals, ranging from 3 to 6 , for such herds. Thirty-nine solitary or paired animals were counted, accounting for $8.6 \%$ of the total population. These figures again agree with, though are slightly higher than, Tener's (1965).

\section{GENERAL CONCLUSIONS}

Although most of the work towards the present paper was carried out north of the 73rd parallel, the population estimates and dispersion probably apply to all Banks Island, as there are very few animals south of $73^{\circ} \mathrm{N}$. in the spring (Macpherson 1960). The population estimates must be regarded as conservative. Thus, the present author suggests that the population of caribou was between 5,300 and 8,000 , and of muskoxen between 1,200 and 1,800 - far higher than has ever been supposed.

The habitats selected by caribou and muskoxen overlap to some extent, being apparently determined by the foods available to, or preferred by, these animals. Some competition between muskoxen and caribou may occur for specific marshgrowing grasses and sedges. However, the data obtained during the present study and those of Tener (1963) indicate that caribou are associated with simpler plant communities than are muskoxen. Competition between the two species for food is probably limited both temporally and by preferred feed. Fig. 2 and Table 2 indicate a situation similar to that which Tener (1965) found on Axel Heiberg Island where "the species were almost mutually exclusive". This situation would cause the impact of interspecific competition to be further reduced unless it is in itself manifestation of competition. Further work is clearly needed to elucidate the problem posed here.

Group and herd structures of Peary caribou differ from those of barren-ground caribou, both in size and behaviour. The groups of Peary caribou are generally the smaller. This fact could be the result of a behavioural adaptation to a vegetation (and hence food) which is sparser on the islands of the Arctic than on the mainland (Savile 1961).

Figures for group and herd structures of muskoxen obtained during the present study compare with those given by Tener (1965), but are generally higher in regard to calf production, herd size, and numbers of solitary or paired animals.

In the case of both Peary caribou and muskoxen, geographical areas of high population density support over half of the calving caribou and all the reproductive muskoxen. These areas should be regarded as "critical areas" in the spring for the survival of both species.

The present study, apart from providing additional information on the biology of the two ungulates of the Arctic islands, provides baseline population estimates for comparison with future estimates. 


\section{ACKNOWLEDGEMENTS}

I thank V. D. Hawley and T. Barry, Canadian Wildlife Service, Edmonton, and R. Williams, Northwest Territories Game Management Service, Inuvik, for their advice. Reindeer Air Services, Inuvik, were most helpful, their pilot R. MacKenzie particularly so. I thank the people who have helpfully criticized the manuscript. I am grateful to J. Stephen, Northwest Territories Game Management Service, Fort Good Hope, Northwest Territories, for his help and cheerful companionship; he acted as second observer during the aerial surveys. The work towards this paper was carried out under contract W.R.O. 70/71 no. 46 of the Western Region of the Canadian Wildlife Service. I am grateful to Memorial University of Newfoundland for contributing towards the cost of publication.

\section{REFERENCES}

MaCPherson, A. H. 1959. A Preliminary Survey of Arctic Wildlife Resources. (Canadian Wildlife Service, Ottawa, unpublished report).

1960. Notes on Abundance and Distribution of Mammals on Banks Island and Victoria Island, N.W.T. in the Summer of 1959. (Canadian Wildlife Service, Ottawa, unpublished report).

MAHER, W. J. and R. T. Holmes. 1963. Observations of muskoxen on Banks Island, Northwest Territories, Canada. Arctic, 16: 275-6.

MANNING, T. H. and A. H. MACPHERSON. 1958. The mammals of Banks Island. Arctic Institute of North America Technical Paper no. 2, 74 pp.

MCEWEN, E. H. 1952. Polar caribou-Rangifer pearyi. (Canadian Wildlife Service, Ottawa, unpublished report).

PORSILD, A. E. 1955. The vascular plants of the western Canadian Arctic Archipelago. Canada, National Museum, Bulletin 135.

SAVILE, D. B. O. 1961. Bird and mammal observation of Ellef Ringnes Island in 1960. Canada, National Museum, Natural History Paper no. 9, 6 pp.

STEFANSSON, v. 1921. The Friendly Arctic. New York: Macmillan and Co.

STEPHEN, J. R. 1970. A Report on Banks Island Muskoxen and Caribou Survey, June 1970. (Northwest Territories Game Management Service, unpublished report).

TENER, J. S. 1958. The distribution of muskoxen in Canada. Journal of Mammalogy, 39: 389-408.

1963. Queen Elizabeth Island Game Survey, 1961. Canadian Wildlife Service Occasional Papers, no. 4, 50 pp.

1965. Muskoxen in Canada, a biological and taxonomic review. Canadian

Wildlife Service Monograph no. 2, $166 \mathrm{pp}$. 